\title{
mRNA expression pattern of retinoic acid and retinoid $X$ nuclear receptor subtypes in human thyroid papillary carcinoma
}

\author{
DANA MACEJOVÁ ${ }^{1}$, ŠTEFAN GALBAVÝ $^{2,3}$, JÁN PODOBA $^{4}$, LUCIA BIALEŠOVÁ ${ }^{1}$ and JÚLIUS BRTKO ${ }^{1}$ \\ ${ }^{1}$ Institute of Experimental Endocrinology, Slovak Academy of Sciences, 83306 Bratislava; ${ }^{2}$ Department of Pathology, \\ St. Elizabeth University of Health and Social Sciences and St. Elisabeth Institute of Oncology, 81250 Bratislava; \\ ${ }^{3}$ Institute of Forensic Medicine, Faculty of Medicine, Comenius University, 81372 Bratislava; ${ }^{4}$ Department of \\ Endocrinology, St. Elisabeth Institute of Oncology, 81250 Bratislava, Slovak Republic
}

Received June 12, 2013; Accepted July 22, 2013

DOI: $10.3892 /$ or.2013.2670

\begin{abstract}
Retinoids have shown potential for the inhibition of tumour growth and progression. The objective of this study was to investigate retinoic acid nuclear receptor subtypes RAR/ RXR and iodothyronine 5'-deiodinase, type I expression pattern in papillary thyroid tumour tissue of 26 patients in order to compare with those of the non-neoplastic thyroid tissue of the corresponding patients. The expression of selected parameters mRNA was examined by semi-quantitative RT-PCR. Papillary thyroid carcinoma (PTC) expressed RXR $\gamma$, when compared to non-neoplastic thyroid tissues of the corresponding patients that were lacking expression of RXR $\gamma$ or its expression was very low. Moreover, we found significantly increased expression of RAR $\alpha$ and RAR $\gamma$ in the overall group of PTC. This increase was detected in cases with positive lymph node metastasis (LNM), but not in cases with negative LNM. RAR $\beta$ was significantly reduced in the subgroup of classic variant (CV). We also detected absence or significantly lower expression of hDIO1 mRNA in tumour tissue when compared to non-neoplastic tissue in both overall PTC cases and in the CV subgroup. However, the significantly decreased levels of hDIO1 mRNA were detected in cases with negative LNM but not in cases with positive LNM when compared to corresponding non-tumour tissue in both overall PTC cases and in the CV subgroup. Differences in RAR and RXR subtype mRNA expression patterns in various
\end{abstract}

Correspondence to: Dr Dana Macejová, Institute of Experimental Endocrinology, Slovak Academy of Sciences, Vlárska 3, 83306 Bratislava, Slovak Republic

E-mail: ueenmace@savba.sk

Abbreviations: PTC, papillary thyroid carcinoma; CV, classic variant; MT, mixed type; OV, oncocytic variant; TC, tall-cell variant; WT, warthin-like type; LNM, lymph node metastasis; RAR, retinoic acid receptor; RXR, retinoid X receptor; TR, thyroid hormone receptor; SMRT, silencing mediator for retinoic acid and thyroid hormone receptor; SRC-1, steroid receptor coactivator-1; hDIO1,2,3, 3,5,3'-triiodo-L-iodothyronine 5'-deiodinase, type 1,2,3

Key words: papillary thyroid carcinoma, nuclear receptor, retinoic acid receptor, retinoid X receptor, deiodinase, RT-PCR
PTCs may contribute to the immunochemistry data available, and may thus find exploitation in clinical oncology, particularly in the differential diagnosis of thyroid neoplasms.

\section{Introduction}

Papillary thyroid carcinomas (PTCs) are the most common types of thyroid cancer representing $>70 \%$ of all thyroid malignancies. PTC occurs more frequently in women, where the most common etiologic factor is radiation, but genetic susceptibility and other factors also contribute to its development $(1,2)$. PTC belongs to a class of well-differentiated thyroid cancers known for a favourable prognosis when the diagnosis, staging, treatment and risk of recurrence are carefully managed. It represents a large group of thyroid carcinomas with several histologic variants including microcarcinomas, follicular variants, encapsulated variants, diffuse sclerosing variants, oxyphilic cell variants, Warthin-like variant (WV), oncocytic variant $(\mathrm{OV})$ and 2 more aggressive variants, the tall-cell variant (TC) and the columnar cell variant $(2,3)$. While PTC is known for its favourable prognosis, $\sim 10 \%$ of patients develop recurrence in lymph node and/or distant organs $(4,5)$. One of the important diagnostic characteristics of PTC is nuclear changes, which include subtle irregularities in the nuclear contour and size, deep nuclear grooves, and pseudo inclusions resulting from cytoplasmic invaginations (6). PTC is known for its tendency for multifocality, ranging from $18-46 \%$, depending on the series. Lymph node involvement is common, occurring in $\sim 30 \%$ of patients. Extrathyroidal extension ranges from $8-32 \%$ of cases. The most common site of extrathyroidal extension is the surrounding muscle $(8 \%)$, followed by the recurrent laryngeal nerve $(6 \%)$ and trachea $(5 \%)(7,8)$. Distant metastases are reported in only $1-25 \%$ of PTC patients, representing the lowest rate of all well-differentiated thyroid carcinomas (2).

Both retinoids and rexinoids are known to affect a broad spectrum of biochemical and molecular biology reactions in organisms, but their associated effects are improbable without fully functioning nuclear receptors. Hence, research on the role and function of nuclear retinoid and retinoid $\mathrm{X}$, which play a role as biologically active ligand inducible transcription factors, belongs to the dynamically developing branch of molecular endocrinology. Thus, retinoids are involved in the 
Table I. Primers for semi-quantitative RT-PCR.

\begin{tabular}{|c|c|c|c|c|}
\hline Gene & Sequence & Annealing temp $\left({ }^{\circ} \mathrm{C}\right)$ & Product size (bp) & Ref. \\
\hline RAR $\alpha$ & $\begin{array}{l}\text { 5'-ACCCCCTCTACCCCGCATCTACAAG-3' } \\
\text { 5'-CATGCCCACTTCAAAGCACTTCTGC-3' }\end{array}$ & 60 & 226 & (17) \\
\hline $\operatorname{RAR} \beta$ & $\begin{array}{l}\text { 5'-ATTCCAGTGCTGACCATCGAGTCC-3' } \\
\text { 5'-CCTGTTTCTGTGTCATCCATTTCC-3' }\end{array}$ & 62 & 349 & (17) \\
\hline $\operatorname{RAR} \gamma$ & $\begin{array}{l}\text { 5'-TACCACTATGGGGTCAGC-3' } \\
\text { 5'-CCGGTCATTTCGCACAGCT-3' }\end{array}$ & 60 & 195 & (17) \\
\hline $\mathrm{RXR} \alpha$ & $\begin{array}{l}\text { 5'-TTCGCTAAGCTCTTGCTC-3' } \\
\text { 5'-ATAAGGAAGGTGTCAATGGG-3' }\end{array}$ & 58 & 113 & (17) \\
\hline $\mathrm{RXR} \beta$ & $\begin{array}{l}\text { 5'-GAAGCTCAGGCAAACACTAC-3' } \\
\text { 5'-TGCAGTCTTTGTTGTCCC-3' }\end{array}$ & 58 & 111 & (17) \\
\hline $\mathrm{RXR} \gamma$ & $\begin{array}{l}\text { 5'-GCAGTTCAGAGGACATCAAGCC-3' } \\
\text { 5'-GCCTCACTCTCAGCTCGCTCTC-3' }\end{array}$ & 62 & 352 & $(17)$ \\
\hline GAPDH & $\begin{array}{l}\text { 5'-TGAACGGGAAGCTCACTGG-3' } \\
\text { 5'-TCCACCACCCTGTTGCTGTA-3' }\end{array}$ & 60 & 307 & (17) \\
\hline $\mathrm{TR} \alpha$ & $\begin{array}{l}\text { 5'-AGGAGAACAGTGCCAGGTCA-3' } \\
\text { 5'-TCTTGAAGCGGCACAGCTGG-3' }\end{array}$ & 60.4 & 297 & \\
\hline $\operatorname{TR} \beta$ & $\begin{array}{l}\text { 5'-AACTACAGGTATAAGGCTGATTCAC-3' } \\
\text { 5'-ATGCTTCTCTGCGTATATGCC-3' }\end{array}$ & 59 & 295 & \\
\hline SMRT & $\begin{array}{l}\text { 5'-GACCCCACCTCCATACCCCG-3' } \\
\text { 5'-GGGAGGTAGGCAAGGCGGTC-3' }\end{array}$ & 64.5 & 392 & \\
\hline SRC-1 & $\begin{array}{l}\text { 5'-GCCCTGGGAGCTCCATGGTG-3' } \\
\text { 5'-CTCTTCTGCTGGGCCTGGGG-3' }\end{array}$ & 63 & 605 & \\
\hline hDIO1 & $\begin{array}{l}\text { 5'-GGACATCAGAAATCACCAGA-3' } \\
\text { 5'-TTCCTCTGGGTTGTAGTTCC-3' }\end{array}$ & 57 & 300 & \\
\hline
\end{tabular}

complex arrangements of physiological and developmental responses in several tissues of higher vertebrates that include embryonic development, vision, reproduction, bone formation, haematopoiesis, metabolism, growth and differentiation of a variety of cell types, apoptosis and processes of carcinogenesis (9-11). The diversity of the retinoic acid-induced signalling pathway is associated with at least 3 isotypes of nuclear receptors [all-trans retinoic acid, $\operatorname{RAR}(\alpha, \beta$ and $\gamma)$ ] and 3 isotypes of nuclear receptors [9-cis retinoic acid, RXR or retinoid $\mathrm{X}$ receptors $(\alpha, \beta$ and $\gamma)$ ]. Changes of expression of RARs and RXRs during the dedifferentiation/redifferentiation and tumour progression in thyroid carcinomas were first demonstrated by Schmutzler et al (12). Subsequently, changes in expression of RARs and RXRs during the dedifferentiation and tumour progression in PTC were demonstrated in patients treated in Japan by Tang et al (14) and Liu et al (13).

Thyroid hormone influences a wide variety of biological events, including the balance between proliferation and differentiation. The conversion of pro-hormone T4 into the biologically active hormone T3 is catalyzed by iodothyronine deiodinases [type 1 (hDIO1) and type 2 (hDIO2)] (15).

The expression status of RARs and RXRs and their association with the clinicopathological parameters is clearly requisite, hence the aim of this study was to investigate the expression status of both RAR and RXR subtypes in 26 patients who had undergone surgery for PTC.

\section{Materials and methods}

Human samples. Tumour and surrounding normal thyroid tissue were randomly collected from 26 patients diagnosed with PTC at the Endocrine or Head and Neck Surgery Divisions St. Elisabeth Oncology Hospital in Bratislava, Slovakia. Sample tissues were immediately frozen in liquid nitrogen and stored at $-70^{\circ} \mathrm{C}$. Surgery was independently indicated by attending physicians. Tumours were histologically classified and the clinical stage was determined by the tumour, node, metastasis system (16). The study was approved by the Ethics Committee of the St. Elisabeth Oncology Hospital in Bratislava, Slovakia.

mRNA analyses. Total RNA was isolated using TRIzol reagent according to the manufacturer's instructions. The concentration of RNA was determined by spectrophotometry at $260 \mathrm{~nm}$ and the purity assessed from the ratio of absorbance $A_{260 n m} / A_{280 n m}$. Reverse transcription (RT) was performed with $2 \mu \mathrm{g}$ of total DNAse I-treated (Thermo Scientific, Germany) RNA and the Ready-to-Go You-Prime First-Strand Beads (Amersham Pharmacia Biotech, Inc., USA) according to the manufacturer's protocol. PCR was performed in $25 \mu \mathrm{l}$ total volume comprising $2 \mu \mathrm{l}$ RT mixture, 1X PCR buffer, $1.5 / 3$ mmol. $\mathrm{l}^{-1}$ $\mathrm{MgCl}_{2}$ (RARs, RXRs and GAPDH/TRs, SMRT, SRC-1 and hDIO1), 0.2 mmol. $1^{-1} \mathrm{dNTP}, 25 \mathrm{pmol}$ of each specific gene primer set and $0.6 \mathrm{U}$ of DyNAzyme II DNA polymerase 
Table II. Clinicopathological parameters of the 26 cases of PTC.

\begin{tabular}{|c|c|c|c|c|c|}
\hline Patient & Gender & $\begin{array}{c}\text { Age } \\
\text { (years) }\end{array}$ & $\begin{array}{c}\text { Type of } \\
\text { PTC }\end{array}$ & $\begin{array}{c}\text { Diameter } \\
(\mathrm{mm})\end{array}$ & $\begin{array}{c}\text { LNM } \\
\text { (total/no. of } \\
\text { positive) }\end{array}$ \\
\hline P1 & $\mathrm{F}$ & 59 & $\mathrm{TC}$ & 25 & $6 / 0$ \\
\hline $\mathrm{P} 2$ & $\mathrm{~F}$ & 39 & $\mathrm{OV}$ & 30 & $18 / 1^{+}$ \\
\hline P3 & $\mathrm{F}$ & 32 & WV & 22 & $8 / 0$ \\
\hline $\mathrm{P} 4$ & $\mathrm{~F}$ & 81 & MT & 30 & $10 / 8^{+}$ \\
\hline P5 & M & 27 & MT & 12 & $9 / 5^{+}$ \\
\hline P6 & $\mathrm{F}$ & 70 & MT & 40 & $8 / 8^{+}$ \\
\hline P7 & $\mathrm{F}$ & 62 & MT & 15 & $7 / 0$ \\
\hline P8 & $\mathrm{F}$ & 36 & MT & 45 & $14 / 7^{+}$ \\
\hline P9 & $\mathrm{F}$ & 72 & $\mathrm{CV}$ & 20 & $3 / 0$ \\
\hline P10 & $\mathrm{F}$ & 56 & $\mathrm{CV}$ & 12 & $18 / 0$ \\
\hline P11 & $\mathrm{F}$ & 46 & $\mathrm{CV}$ & 15 & $4 / 0$ \\
\hline P12 & M & 59 & $\mathrm{CV}$ & 26 & $4 / 0$ \\
\hline P13 & $\mathrm{F}$ & 30 & $\mathrm{CV}$ & 28 & $11 / 0$ \\
\hline P14 & $\mathrm{F}$ & 70 & $\mathrm{CV}$ & 12 & $15 / 0$ \\
\hline P15 & M & 53 & $\mathrm{CV}$ & 35 & $12 / 0$ \\
\hline P16 & M & 34 & $\mathrm{CV}$ & 40 & $4 / 0$ \\
\hline P17 & M & 66 & $\mathrm{CV}$ & 40 & $7 / 0$ \\
\hline P18 & M & 39 & $\mathrm{CV}$ & 25 & $8 / 1^{+}$ \\
\hline P19 & $\mathrm{M}$ & 33 & $\mathrm{CV}$ & 17 & $4 / 2^{+}$ \\
\hline P20 & $\mathrm{F}$ & 36 & $\mathrm{CV}$ & 28 & $10 / 10^{+}$ \\
\hline P21 & M & 29 & $\mathrm{CV}$ & 30 & $9 / 4^{+}$ \\
\hline P22 & $\mathrm{F}$ & 33 & $\mathrm{CV}$ & 27 & $4 / 3^{+}$ \\
\hline $\mathrm{P} 23$ & $\mathrm{~F}$ & 57 & $\mathrm{CV}$ & 22 & $25 / 15^{+}$ \\
\hline $\mathrm{P} 24$ & M & 47 & $\mathrm{CV}$ & 12 & $4 / 1^{+}$ \\
\hline $\mathrm{P} 25$ & $\mathrm{~F}$ & 51 & $\mathrm{CV}$ & 26 & $6 / 1^{+}$ \\
\hline P26 & M & 55 & $\mathrm{CV}$ & 12 & $8 / 2^{+}$ \\
\hline
\end{tabular}

PTC, papillary thyroid carcinoma; F, female; M, male; TC, tall-cell variant; OV, oncocytic variant; WV, Warthin-like variant; MT, mixed type; CV, classic variant; LNM, lymph node metastasis.

(Finnzymes OY, Finland) in buffer provided by the manufacturer. PCR was undertaken following treatment of samples at $94^{\circ} \mathrm{C}$ for $3 \mathrm{~min}$ to inactivate reverse transcriptase, which consisted of 35 cycles of denaturing $\left(95^{\circ} \mathrm{C}, 60 \mathrm{sec}\right)$, annealing $(60 \mathrm{sec})$, extension $\left(72^{\circ} \mathrm{C}, 60 \mathrm{sec}\right)$, and a final extension at $72^{\circ} \mathrm{C}$ for $10 \mathrm{~min}$. The oligonucleotide of the primers employed in this study as well as the corresponding annealing times are summarized in Table I (17). These conditions were proven to be in the log phase for each amplified sequence. Triton tumour tissue was used as a positive control (18). A negative control without cDNA template was run with every assay batch in order to assess overall specificity. The PCR products were separated on $2 \%$ agarose gel and stained with GelRed ${ }^{\mathrm{TM}}$ dye (Biotium, USA). The band intensities were measured using an STS 6220I Documentation System (Ultralum, USA) and normalized to the band intensity of the PCR product corresponding to the housekeeping gene GAPDH.

Statistical analysis. Data are expressed as means (SD) or as medians (range 5-95\%). Statistical significance was assessed using an ANOVA (Bonferroni) test.

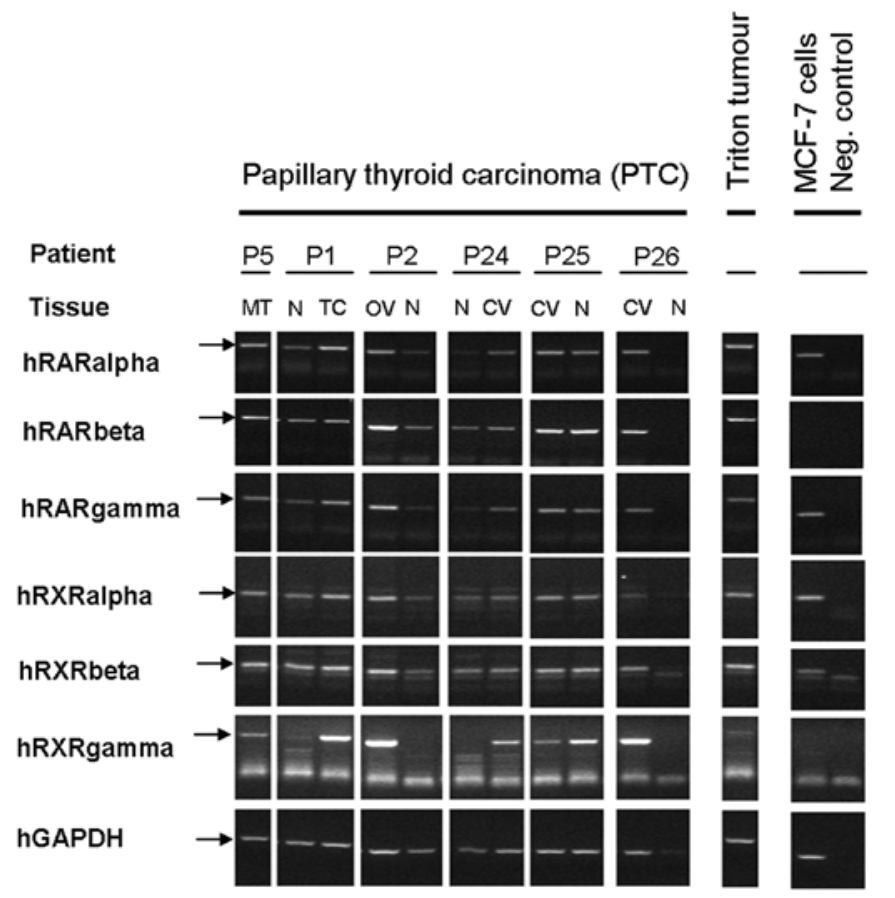

Figure 1. Representative expression pattern of selected parameters in non-tumour and tumour thyroid tissue. PTC, papillary thyroid carcinoma; MT, mixed type; $\mathrm{TC}$, tall-cell variant; $\mathrm{OV}$, oncocytic variant; $\mathrm{CV}$, classic variant.

\section{Results}

Ten males and 16 females were enrolled in this study. Mean age at surgery was $48.9 \pm 15.6$ years (means \pm SD). Clinicopathological parameters of the 26 cases of PTC are presented in Table II. Various types of PTC were recognized: 18 cases of classic variant (CV) $(69.3 \%), 5$ cases of mixed type (MT) $(19.3 \%), 1$ case of TC (3.8\%), 1 case of OV (3.8\%) and 1 case of WV $(3.8 \%)$. The mean tumour size was $24.8 \pm 9.9 \mathrm{~mm}$ (means $\pm \mathrm{SD}$, median=25.5). Only 3 tumours were measured at $\geq 40 \mathrm{~mm}$. Histologically confirmed lymph node metastasis (LNM) was identified in 14 cases at surgery, but was absent in the other 12 cases.

The objective of this study was to investigate all-trans retinoic acid/9-cis retinoic acid nuclear receptor subtypes (RAR $\alpha$, $\operatorname{RAR} \beta, \operatorname{RAR} \gamma, \operatorname{RXR} \alpha, \operatorname{RXR} \beta, \operatorname{RXR} \gamma)$, thyroid hormone receptors (TR $\alpha, \mathrm{TR} \beta$ ), nuclear receptor coregulators (SMRT, SRC-1) and iodothyronine 5'-deiodinase, type I expression pattern in papillary thyroid tumour tissue of patients in order to compare with the expression pattern of the non-neoplastic thyroid tissue of the corresponding patients. Fig. 1 shows representative expression pattern of selected parameters.

Statistically increased levels of RAR $\alpha$ mRNA in tumour tissue $(\mathrm{P}<0.05)$ were detected when compared to the nonneoplastic tissue (Fig. 2A and B). This increase was also detected in cases with positive LNM but not in cases with negative LNM (Fig. 2C) when compared to corresponding non-tumour tissue. However, there was no significant increase of RAR $\alpha$ mRNA levels in the subgroup of CV of PTC (data not shown).

In this study of overall PTC cases, no significantly altered expression of RAR $\beta$ was detected when compared to non-tumour thyroid tissue (Fig. 3) or when the data were 

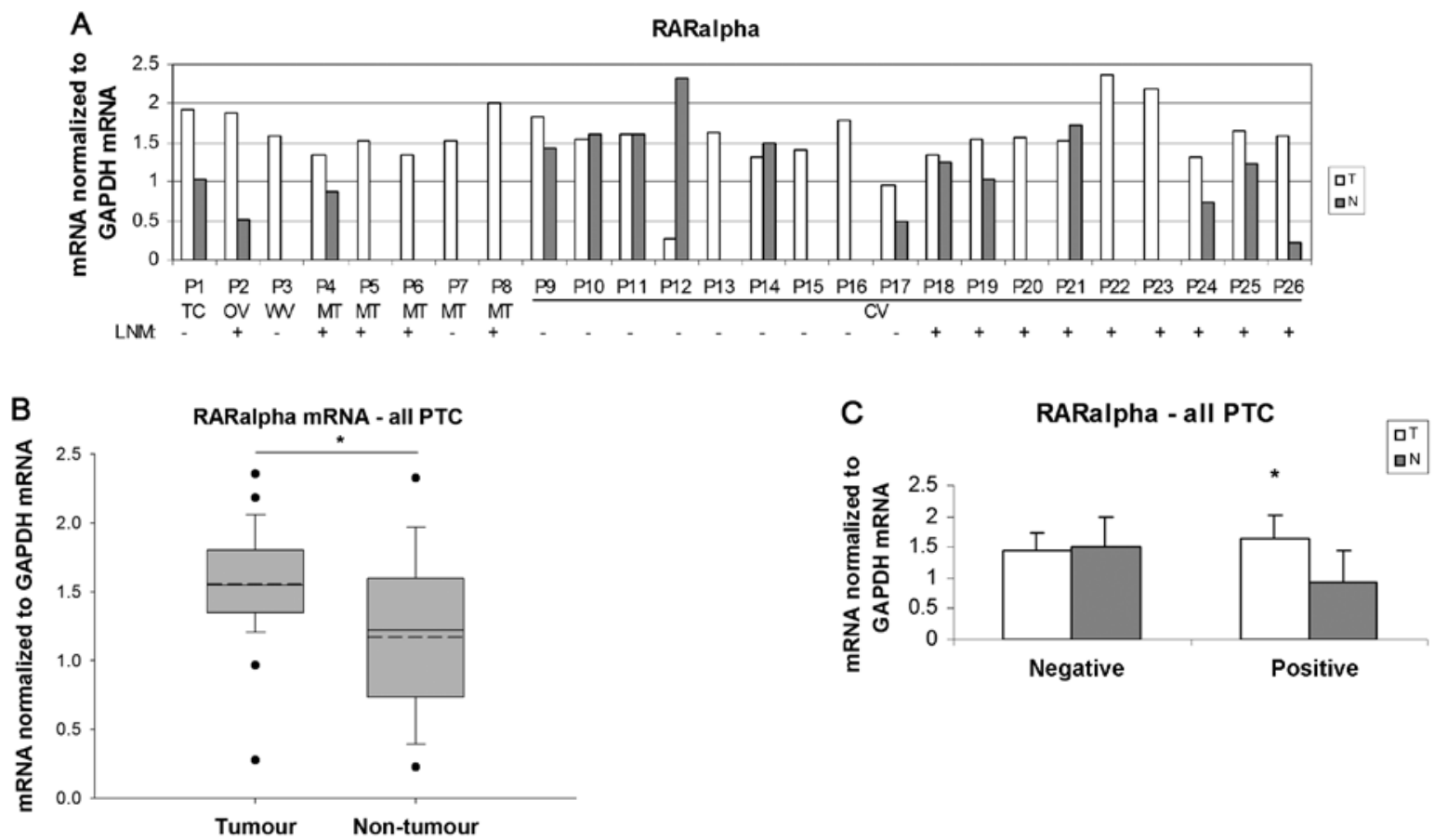

Figure 2. (A) Expression pattern of RAR $\alpha$ mRNA. PTC, papillary thyroid carcinoma; MT, mixed type; TC, tall-cell variant; OV, oncocytic variant; WV, Warthinlike variant; CV, classic variant. (B) Relative levels of RAR $\alpha$ mRNA in tumour (T) and non-tumour thyroid tissue (N). Data are expressed as medians (range 5-95\%). (C) Relative levels of RAR $\alpha$ mRNA in PTC with negative or positive lymph node metastasis. Data are expressed as means \pm SD. Bonferroni test "P<0.05.
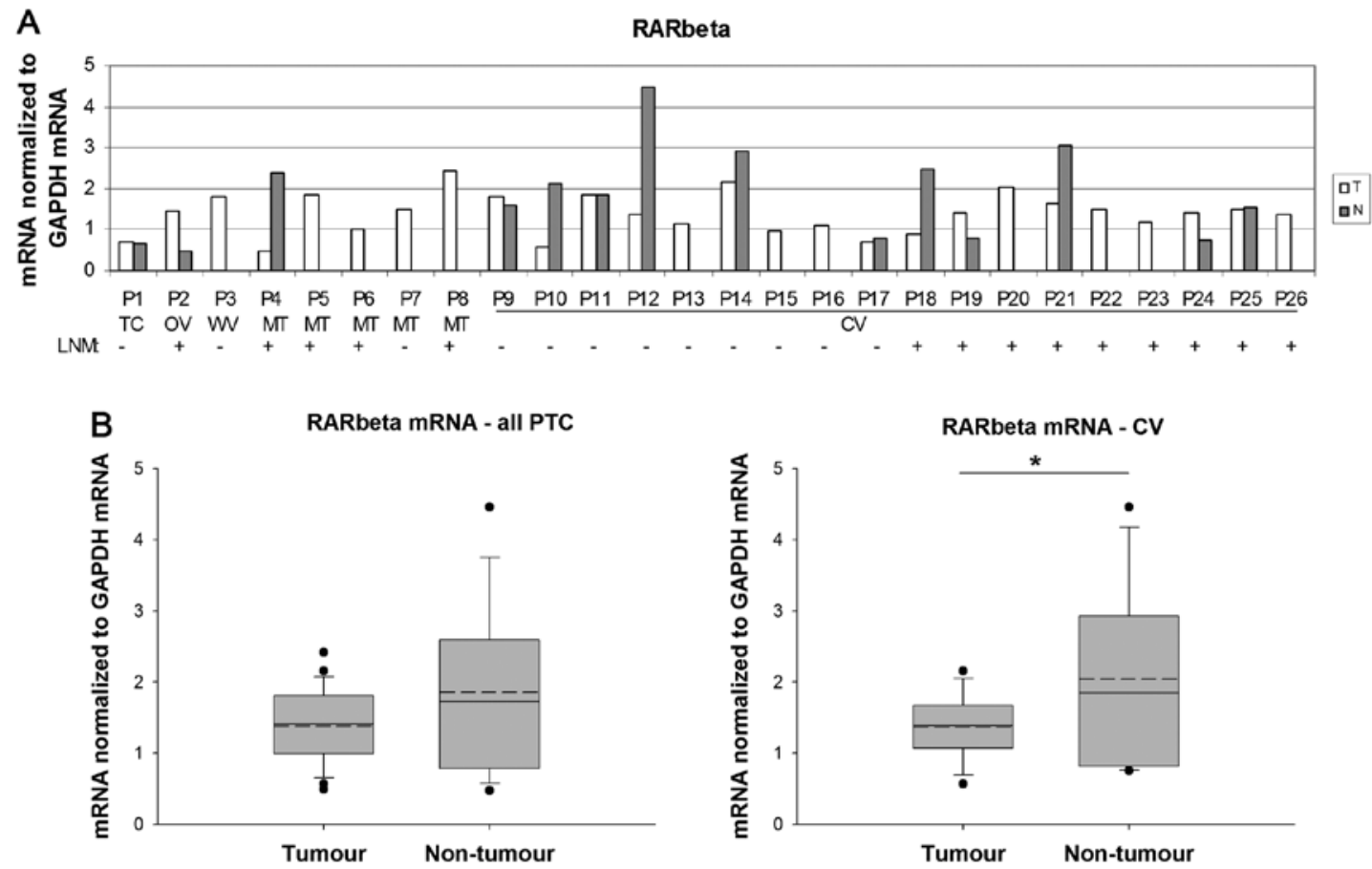

Figure 3. (A) Expression pattern of RAR $\beta$ mRNA. PTC, papillary thyroid carcinoma; MT, mixed type; TC, tall-cell variant; OV, oncocytic variant; WV, Warthin-like variant; CV, classic variant. (B) Relative levels of RAR $\beta$ mRNA in tumour (T) and non-tumour thyroid tissue (N) in all PTC cases and in CV, respectively. Data are expressed as medians (range 5-95\%). Bonferroni test ${ }^{*} \mathrm{P}<0.05$.

considered as positive or negative LNM cases (data not shown). However, there were significantly $(\mathrm{P}<0.05)$ reduced RAR $\beta$ mRNA levels in the CV subgroup of PTC (Fig. 3B).

Normal tissue samples exhibited an overall lower expression of RAR $\gamma$ mRNA when compared to PTC $(\mathrm{P}<0.01)$ (Fig. 4A and B). Significantly increased levels were detected in cases with positive LNM, but not in PTC with negative LNM ( $\mathrm{P}<0.01$ (Fig. 4C). However, we did not detect this increase in the CV subgroup of PTC (data not shown).

Tumour tissue showed a significantly higher expression of $\mathrm{RXR} \gamma$ than non-neoplastic thyroid tissue $(\mathrm{P}<0.001)$ in both overall PTC cases and in the CV subgroup (Fig. 5A and B). 

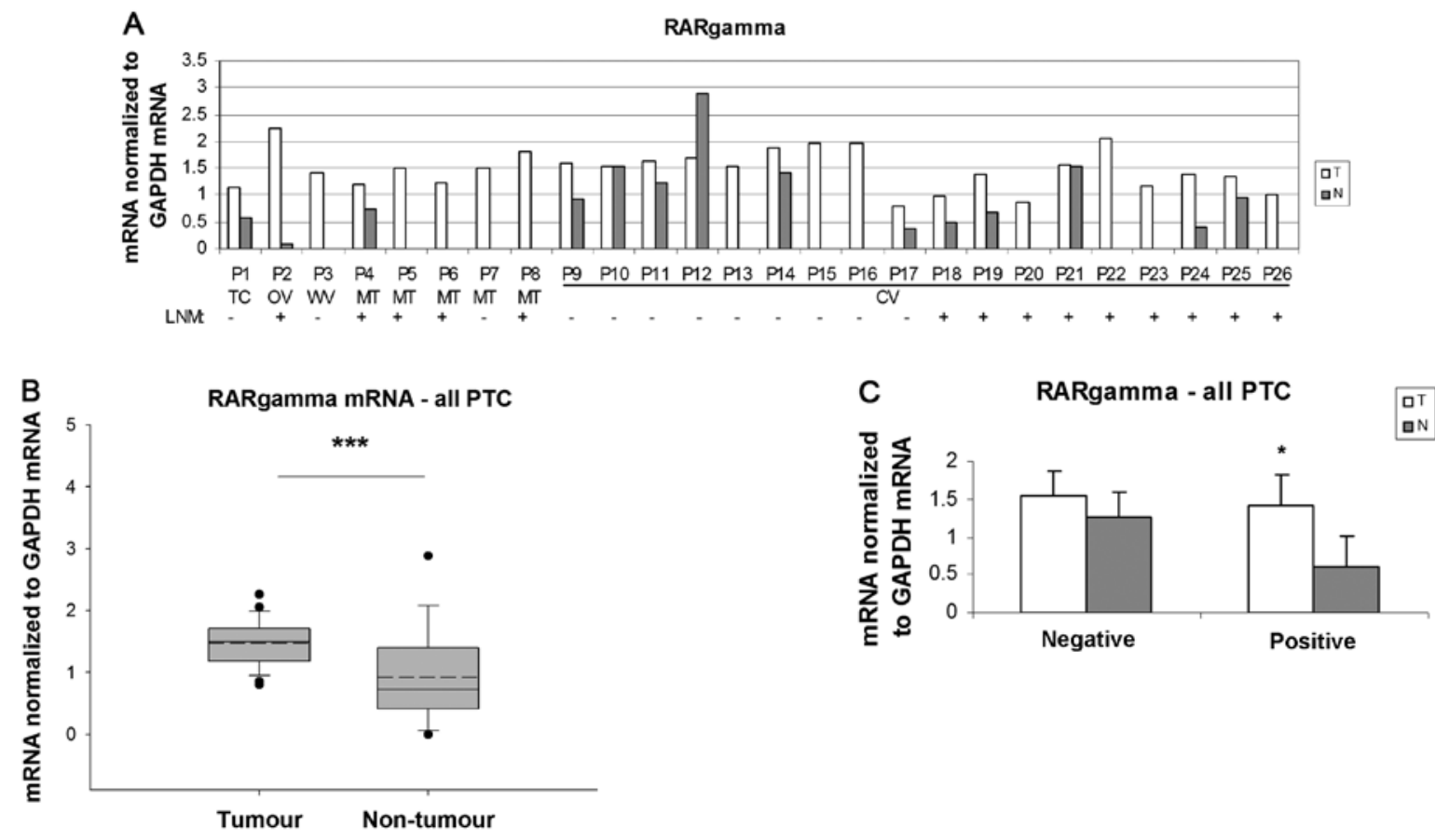

Figure 4. (A) Expression pattern of RAR $\gamma$ mRNA. PTC, papillary thyroid carcinoma; MT, mixed type; TC, tall-cell variant; OV, oncocytic variant; WV, Warthin-like variant; CV, classic variant. (B) Relative levels of RAR $\gamma$ mRNA in tumour (T) and non-tumour thyroid tissue (N) in all PTC cases. Data are expressed as medians (range 5-95\%). (C) Relative levels of RAR $\gamma$ mRNA in PTC with negative or positive lymph node metastasis. Data are expressed as means \pm SD. Bonferroni test ${ }^{*} \mathrm{P}<0.05 ;{ }^{* * *} \mathrm{P}<0.001$.
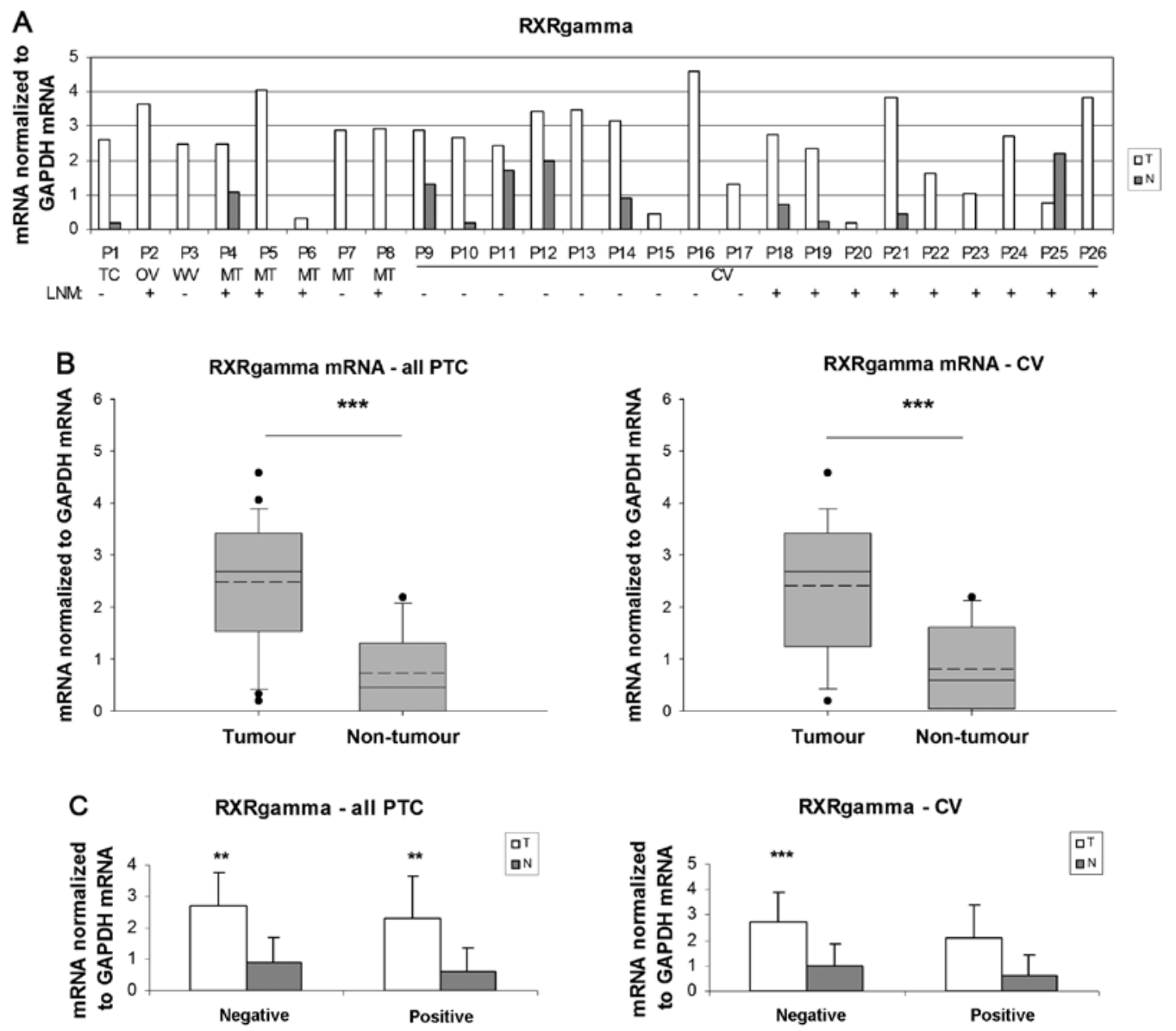

Figure 5. (A) Expression pattern of RXR $\gamma$ mRNA. PTC, papillary thyroid carcinoma; MT, mixed type; TC, tall-cell variant; OV, oncocytic variant; WV, Warthin-like variant; CV, classic variant. (B) Relative levels of RXR $\gamma$ mRNA in tumour (T) and non-tumour thyroid tissue (N) in all PTC cases and in CV, respectively. Data are expressed as medians (range 5-95\%). (C) Relative levels of RXR $\gamma$ mRNA in all PTC cases and in CV with negative or positive lymph node metastasis, respectively. Data are expressed as means \pm SD. Bonferroni test ${ }^{* * *} \mathrm{P}<0.01 ;{ }^{* * *} \mathrm{P}<0.001$. 


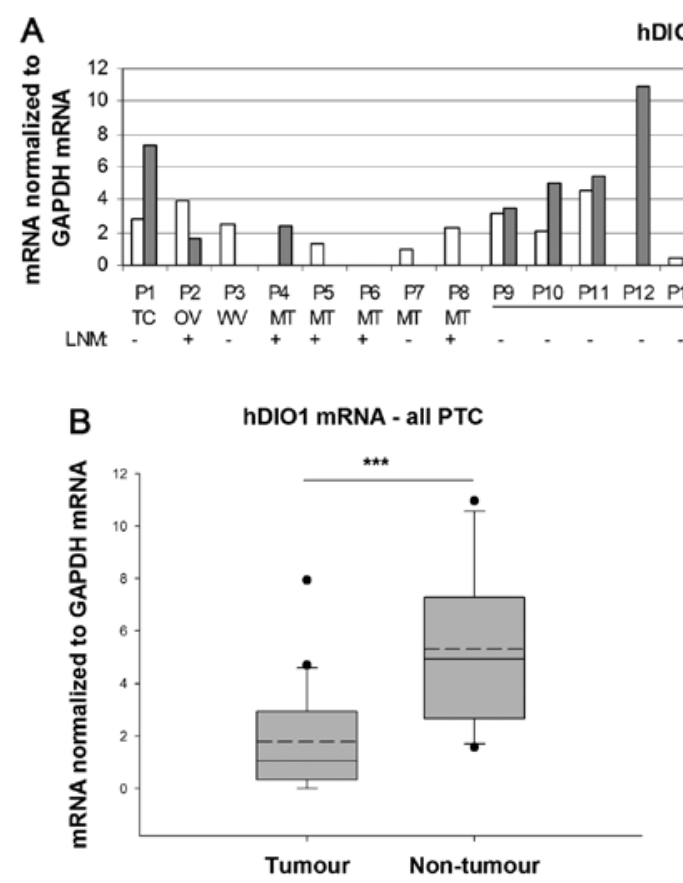

hDI01
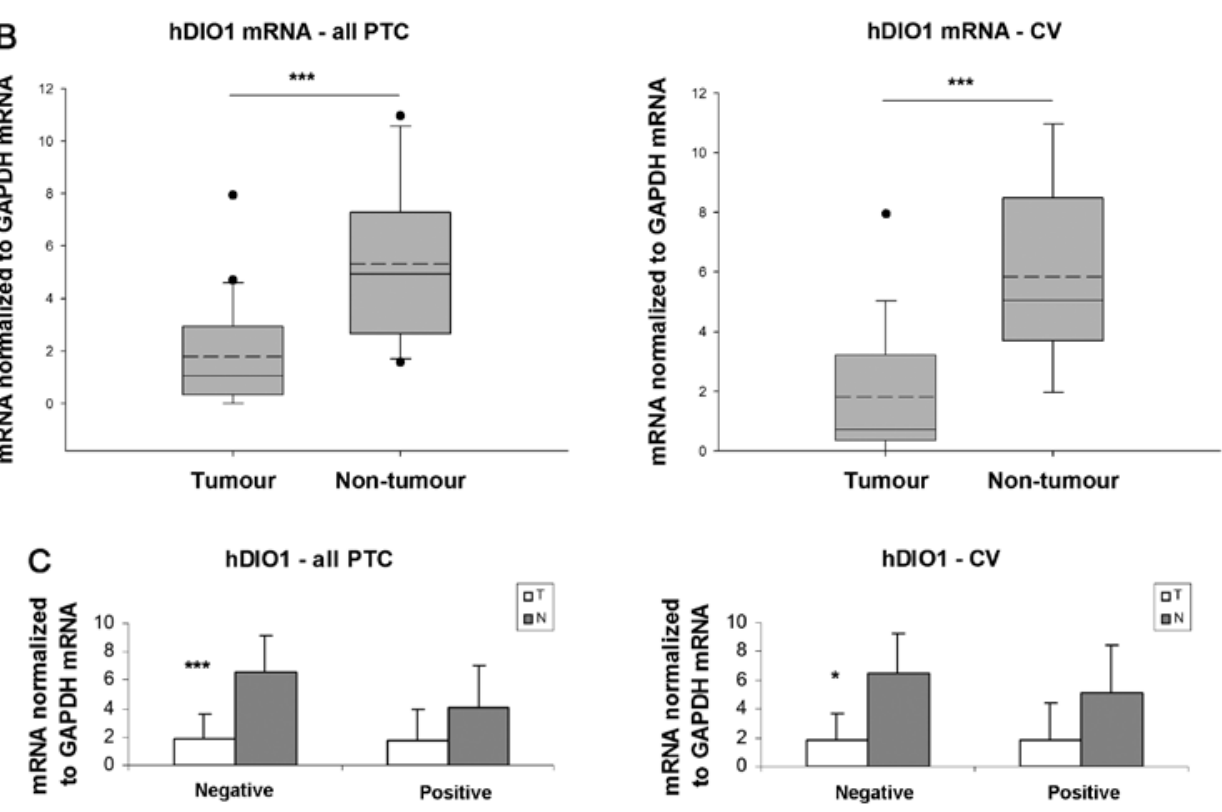

Figure 6. (A) Expression pattern of hDIO1 mRNA. PTC, papillary thyroid carcinoma; MT, mixed type; TC, tall-cell variant; OV, oncocytic variant; WV, Warthin-like variant; CV, classic variant. (B) Relative levels of hDIO1 mRNA in tumour (T) and non-tumour thyroid tissue (N) in all PTC cases and in CV, respectively. Data are expressed as medians (range 5-95\%). (C) Relative levels of hDIO1 mRNA in all PTC cases and in CV with negative or positive LNM, respectively. Data are expressed as means $\pm \mathrm{SD}$. Bonferroni test ${ }^{*} \mathrm{P}<0.05 ;{ }^{* * *} \mathrm{P}<0.001$.

This increase was also detected in cases with positive LNM and negative LNM (Fig. 5C) when compared to corresponding non-tumour tissue $(\mathrm{P}<0.01)$. However, in the $\mathrm{CV}$ subgroup, the significantly higher levels of RXR $\gamma$ mRNA in PTC were detected only in cases with negative LNM $(\mathrm{P}<0.01)$ but not in cases with positive LNM (Fig. 5C).

The expression of hDIO1 mRNA was subsequently studied. The results were consistent with previous literature data in that we detected either the absence or significantly lower expression of this gene in tumour tissue when compared to non-neoplastic tissue in both overall PTC cases and in the CV subgroup (Fig. 6A and B). However, these significantly decreased levels of hDIO1 mRNA were detected in cases with negative LNM but not in cases with positive LNM (Fig. 6C) when compared to corresponding non-tumour tissue in both overall PTC cases and in the CV subgroup $(\mathrm{P}<0.001$ and $\mathrm{P}<0.05$, respectively).

In the present study, the results showed that there were no significant differences in expression of $R X R \alpha, R X R \beta$, TR $\alpha$, TR $\beta$, coactivator SRC-1 and corepressor SMRT mRNA between tumour thyroid tissue and normal tissue samples. However, higher expression of SMRT mRNA in normal tissue samples of patients with positive LNM was detected when compared to patients with negative LNM $(\mathrm{P}<0.05)$ (data not shown).

\section{Discussion}

Papillary thyroid cancer (PTC) is the most frequent histotype, accounting for $>80 \%$ of all thyroid malignancies. While PTC is generally associated with a favourable prognosis, $5-20 \%$ of patients develop tumour recurrence and $10 \%$ have distant metastasis (19). PTC can be further divided into several histotypes. Tall-cell variant (TC) papillary carcinoma is characterized by tall columnar cells eccentric nuclei located adjacent to the basement membrane (20). Warthin-like papillary thyroid carcinoma, a very rare variant of PTC, is histologically characterized as a cystic or solid-cystic thyroid nodule with large, polygonal cells with abundant eosinophilic, finely granular cytoplasm lines on the papillae surrounded by dense lymphocytic infiltrate $(21,22)$. Five variants of PTC were detected in this study: 18 cases of classic variant (CV; 69.3\%), 5 cases of mixed type (MT) (19.3\%), 1 case of TC (3.8\%), 1 case of oncocytic variant (OV; 3.8\%) and 1 case of Warthin-like variant (WV) (3.8\%). The mean tumour size was $24.8 \pm 9.9 \mathrm{~mm}$. Only 3 tumours were $\geq 40 \mathrm{~mm}$. Histologically-confirmed lymph node metastasis (LNM) was identified in 14 cases at surgery.

Hoftijzer et al (23) found an increased expression of the cytoplasmic fraction of RAR $\alpha, \operatorname{RAR} \gamma, \operatorname{RXR} \beta$ protein, and a decreased expression of the nuclear fraction of RAR $\beta, \operatorname{RAR} \gamma$, and RAR $\alpha$ protein in PTCs compared with benign thyroid 
tissue. However, in this study, increased expression of mRNA of RAR $\alpha, R A R \gamma$ and RXR $\gamma$ in overall PTC cases and/or in the CV subgroup of PTC cases was detected using RT-PCR. Several studies reported reduced RAR $\beta$ expression in PTC using various techniques (immunohistochemistry, RT-PCR), when compared to normal tissue (23). We found statistically decreased levels of RAR $\beta$ in the subgroup of CV of PTC.

Haugen et al (24) found very low levels of RXR $\gamma$ mRNA in all normal thyroid tissue tested, but expression was higher in malignant thyroid tumours in comparison with matched normal tissue stage. In our study, the expression levels of this nuclear receptor were significantly increased in tumour tissue, compared to non-neoplastic tissue. However, we detected 1 patient with increased expression of RXR $\gamma$ mRNA in normal tissue and 3 patients with very low expression of this nuclear receptor subtype which is in agreement with the study of Liu et al (13), who found no statistical significance between RXR $\gamma$ expression and patient age, gender or tumour size, while, conversely, RXR $\gamma$ upregulation mainly occurred in PTCs with extrathyroid invasion, LNM or in advanced tumour. PTC with $\mathrm{RXR} \gamma$ upregulation has been shown to have higher incidence of extrathyroid invasion and LNM, and was more frequent in advanced tumour stages (13). Expression of RAR $\beta$ and RXR $\gamma$ in thyroid carcinomas appears to predict response to retinoids and/or rexinoids in tumour redifferentiation therapy (24). Recently, we showed that in the thyroid non-Hodgkin's lymphoma tissue from all-trans retinoic acid receptors, RAR $\beta$ is the most expressed isoform of RARs. In contrast to normal thyroid tissue lacking in $\mathrm{RXR} \gamma$ expression, thyroid nonHodgkin's lymphoma tissue was found to express that isoform of RXRs at a high level (25). It has been shown that retinoids and rexinoids are able to reduce tumour growth by inhibiting angiogenesis, tumour invasion and metastasis in various human cancer cells $(26,27)$. In our animal MNU-induced mammary gland carcinogenesis, the administration of TTNPB (selective ligand for RAR subtypes) and/or Phytol (precursor of phytanic acid-selective ligand for RXR) markedly reduced tumour progression, as well as tumour incidence and tumour burden, and significantly regulated expression of several nuclear receptor mRNA, coregulators mRNA in tumour tissue or in selected organs (unpublished data). Furthermore, in this study we found all RAR and RXR subtypes differentially expressed in respective patient samples. We conclude, therefore, that retinoids and rexinoids selectively bound to their corresponding receptors may inhibit tumour progression.

Our previous observations demonstrated that thyroid status of animals can influence the progress of rat mammary gland carcinogenesis (28). Thyroid hormone is also able to block oncogenic Ras-mediated proliferation and transcriptional induction of cyclin D1 in neuroblastoma cells (29). Moreover, it has been shown that thyroid carcinogenesis may be associated with mutations in thyroid hormone receptor $\beta$ (TR $\beta)$ gene (30). The conversion of the pro-hormone T4 into the biologically active hormone $\mathrm{T} 3$ is catalyzed by iodothyronine deiodinases (type 1 and type 2) (15). However, in our study, the absence or lower expression of hDIO1 mRNA in tumour tissue was detected when compared to non-neoplastic tissue in both overall PTC cases and in the CV subgroup. These significantly decreased levels of hDIO1 mRNA were, however, detected in cases with negative LNM but not in cases with positive
LNM when compared to corresponding non-tumour tissue in both overall PTC cases and in the CV subgroup. Moreover, several studies have shown diminished or unaltered mRNA levels of deiodinases of both type 1 and 2 in the majority of thyroid neoplasias (reviewed in 15,29). Inactivation of both T4 and T3 is catalysed by type 3 iodothyronine deiodinase via inner-ring deiodination. Romitti et al (29) observed increased levels of activity of this enzyme in all analysed PTC samples and mRNA levels were found to be significantly decreased in PTC when compared to surrounding thyroid tissue. It has been shown that PTC samples from patients with lymph node or distant metastasis displayed significantly higher levels of hDIO3 activity than those samples obtained from patients with intra-thyroidal disease (29). Consequently, the reduction of hDIO2 activity may further decrease levels of intracellular thyroid hormone. These observations indicate a role of intracellular hypothyroidism in the tumour cell proliferation and/or differentiation (29).

It has been shown that Seocalcitol (EB1089), synthetic analogue of vitamin D-ligand for vitamin D receptor belonging to steroid/thyroid/retinoid nuclear receptors family, significantly reduced $\mathrm{K}_{\mathrm{A}}$ and increased $\mathrm{B}_{\max }$ of thyroid receptors in liver of rats with MNU-induced mammary gland carcinomas when compared to healthy animals, treatment with EB1089 or vitamin D significantly prolonged tumour latency, markedly reduced tumour burden and volume (31). Vitamin D also reduced hDIO1 activity in liver of rats with MNU-induced mammary gland carcinomas (31). Treatment of MNU-treated animals with EB1089 and Phytol resulted in markedly reduced mammary gland tumour progression and significantly regulated expression of several nuclear receptor mRNA, coregulators mRNA in tumour tissue or in selected organs (unpublished data). Retinoid receptors (RARs) and thyroid hormone receptors (TRs), as well as vitamin D receptor, act as ligand-inducible transcription factors interacting as heterodimers with retinoid X receptors (RXRs). Thus, these nuclear receptors play a role as ligand-activated, DNA-binding, transacting, transcription-modulating proteins involved in a general molecular mechanism responsible (together with coregulators) for transcriptional responses in target genes. RARs exert both beneficial and detrimental activity; while they have tumour-suppressive activity, they are also teratogenic. Several ligands for RARs and RXRs inhibit carcinogenesis, suppress premalignant epithelial lesions and tumour growth and invasion in a variety of tissues. Novel synthetic retinoid and rexinoid analogues acting through RARs as redifferentiation agents could have a predominant role in treating patients with advanced thyroid cancer.

Our data showed that PTC of investigated patients expressed all subtypes of RARs and RXRs when compared to non-neoplastic thyroid tissues of the corresponding patients that were either lacking RXR $\gamma$ expression or expression was very low. In PTC, expression of $\mathrm{RXR} \gamma$ was enhanced in comparison with that of RXR $\alpha$ or RXR $\beta$.

In conclusion, the molecular mechanisms clearly demonstrate differences in RAR and RXR subtype mRNA expression patterns in PTC as studied by RT-PCR. These findings contribute to this branch of immunochemistry, which offers possibilities for exploitation in clinical oncology, predominantly in the differential diagnosis of thyroid neoplasms. 


\section{Acknowledgements}

The authors thank Dr Mike Scotter (The Food and Environment Research Agency, UK) for editing the English language of the original manuscript. This study was supported by APVV grants (APVV-0120-07, APVV-0160-11), VEGA grant 2/0008/11 and the Centre of Excellence CEMAN grant.

\section{References}

1. Lloyd RV, Buehler D and Khanafshar E: Papillary thyroid carcinoma variants. Head Neck Pathol 5: 51-56, 2011.

2. Slough CM and Randolph GW: Workup of well-differentiated thyroid carcinoma. Cancer Control 13: 99-105, 2006.

3. LiVolsi VA: Papillary thyroid carcinoma: an update. Mod Pathol 24 (Suppl 2): S1-S9, 2011.

4. Bai Y, Kakudo K, Li Y, Liu Z, Ozaki T, Ito Y, Kihara M and Miyauchi A: Subclassification of non-solid-type papillary thyroid carcinoma identification of high-risk group in common type. Cancer Sci 99: 1908-1915, 2008.

5. Bai Y, Kakudo K, Nakamura M, Ozaki T, Li Y, Liu Z, Mori I, Miyauchi A and Zhou G: Loss of cellular polarity/cohesiveness in the invasive front of papillary thyroid carcinoma and periostin expression. Cancer Lett 281: 188-195, 2009.

6. Liu Y, Lee MO, Wang HG, Li Y, Hashimoto Y, Klaus M, Reed JC and Zhang X: Retinoic acid receptor $\beta$ mediates the growth-inhibitory effect of retinoic acid by promoting apoptosis in human breast cancer cells. Mol Cell Biol 16: 1138-1149, 1996.

7. DeGroot LJ, Kaplan EL, McCormick M and Straus FH: Natural history, treatment, and course of papillary thyroid carcinoma. J Clin Endocrinol Metab 71: 414-424, 1990.

8. Hay ID: Papillary thyroid carcinoma. Endocrinol Metab Clin North Am 19: 545-576, 1990

9. Brtko J: Retinoids, rexinoids and their cognate nuclear receptors: character and their role in chemoprevention of selected malignant diseases. Biomed Pap Med Fac Univ Palacky Olomouc Czech Repub 151: 187-194, 2007.

10. Brtko J and Dvorak Z: Role of retinoids, rexinoids and thyroid hormone in the expression of cytochrome p450 enzymes. Curr Drug Metab 12: 71-88, 2011.

11. Brtko $\mathrm{J}$ and Thalhamer J: Renaissance of the biologically active vitamin A derivatives: established and novel directed therapies for cancer and chemoprevention. Curr Pharm Des 9: 2067-2077, 2003.

12. Schmutzler C, Brtko J, Bienert K and Köhrle J: Effects of retinoids and role of retinoic acid receptors in human thyroid carcinomas and cell lines derived therefrom. Exp Clin Endocrinol Diabetes 104 (Suppl 4): S16-S19, 1996.

13. Liu Z, Zhou G, Nakamura M, Bai Y, Li Y, Ozaki T, Mori I, Miyauchi A and Kakudo K: Retinoid X receptor $\gamma$ up-regulation is correlated with dedifferentiation of tumor cells and lymph node metastasis in papillary thyroid carcinoma. Pathol Int 61: 109-115, 2011.

14. Tang W, Nakamura Y, Zuo H, Yasuoka H, Yang Q, Wang X, Nakamura M, Mori I, Miyauchi A and Kakudo K: Differentiation, proliferation and retinoid receptor status of papillary carcinoma of the thyroid. Pathol Int 53: 204-213, 2003.

15. Casula S and Bianco AC: Thyroid hormone deiodinases and cancer. Front Endocrinol (Lausanne) 3: 74, 2012.
16. Greene FL and Sobin LH: The TNM system: our language for cancer care. J Surg Oncol 80: 119-120, 2002.

17. Kimura Y, Suzuki T, Kaneko C, Darnel AD, Moriya T, Suzuki S, Handa M, Ebina M, Nukiwa T and Sasano H: Retinoid receptors in the developing human lung. Clin Sci (Lond) 103: 613-621, 2002.

18. Brtko J, Sejnová D, Ondková S and Macejová D: Malignant Triton tumour exhibits a complete expression pattern of nuclear retinoid and rexinoid receptor subtypes. Gen Physiol Biophys 28: 425-427, 2009.

19. Franceschi S, Boyle P, Maisonneuve P, La Vecchia C, Burt AD, Kerr DJ and MacFarlane GJ: The epidemiology of thyroid carcinoma. Crit Rev Oncog 4: 25-52, 1993.

20. Clark DP and Faquin WC (eds): Thyroid Cytopathology. Springer Science and Business Media Inc., New York, NY, 2011.

21. Amico P, Lanzafame S, Li Destri G, Greco P, Caltabiano R, Vecchio GM and Magro G: Warthin tumor-like papillary thyroid carcinoma with a minor dedifferentiated component: report of a case with clinicopathologic considerations. Case Report Med 2010: 495281, 2010.

22. Paker I, Kokenek TD, Yilmazer D, Seker GE and Alper M: Oncocytic variant of papillary thyroid carcinoma with lymphocytic stroma (Warthin-like variant): report of a case with fine needle variant cytology and review of the literature. Cytopathology 23: 408-410, 2012.

23. Hoftijzer HC, Liu YY, Morreau H, van Wezel T, Pereira AM, Corssmit EP, Romijn JA and Smit JW: Retinoic acid receptor and retinoid $\mathrm{X}$ receptor subtype expression for the differential diagnosis of thyroid neoplasms. Eur J Endocrinol 160: 631-638, 2009.

24. Haugen BR, Larson LL, Pugazhenthi U, Hays WR, Klopper JP, Kramer $\mathrm{CA}$ and Sharma V: Retinoic acid and retinoid $\mathrm{X}$ receptors are differentially expressed in thyroid cancer and thyroid carcinoma cell lines and predict response to treatment with retinoids. J Clin Endocrinol Metab 89: 272-280, 2004.

25. Brtko J, Macejova D and Galbavy S: Thyroid non-Hodgkin's lymphoma expression pattern of nuclear retinoid and rexinoid receptor subtypes. Gen Physiol Biophys 29: 411-413, 2010.

26. Papi A, Rocchi P, Ferreri AM and Orlandi M: RXR $\gamma$ and PPAR $\gamma$ ligands in combination to inhibit proliferation and invasiveness in colon cancer cells. Cancer Lett 297: 65-74, 2010.

27. Yen WC, Prudente RY, Corpuz MR, Negro-Vilar A and Lamph WW: A selective retinoid X receptor agonist bexarotene (LGD1069, targretin) inhibits angiogenesis and metastasis in solid tumours. Br J Cancer 94: 654-660, 2006.

28. Macejova D, Radikova Z, Macho L, Liska J and Brtko J: MNU-induced carcinogenesis of rat mammary gland: effect of thyroid hormone on expression of retinoic acid receptors in tumours of mammary gland. Mol Cell Endocrinol 244: 47-56, 2005.

29. Romitti M, Wajner SM, Zennig N, Goemann IM, Bueno AL, Meyer EL and Maia AL: Increased type 3 deiodinase expression in papillary thyroid carcinoma. Thyroid 22: 897-904, 2012.

30. Weinert LS, Ceolin L, Romitti M, Camargo EG and Maia AL: Is there a role for inherited TR $\beta$ mutation in human carcinogenesis? Arq Bras Endocrinol Metabol 56: 67-71, 2012.

31. Macejova D, Ondkova S and Brtko J: Vitamin D3 affects expression of thyroid hormone receptor alpha and deiodinase activity in liver of MNU-treated Sprague-Dawley rats. Gen Physiol Biophys 28: 363-370, 2009. 